\title{
Publisher Correction: Polymorphic design of DNA origami structures through mechanical control of modular components
}

\author{
Chanseok Lee (iD ${ }^{1}$, Jae Young Lee (i) ${ }^{1}$ \& Do-Nyun Kim (1) ${ }^{1,2}$
}

Correction to: Nature Communications https://doi.org/10.1038/s41467-017-02127-6, published online 12 December 2017

The originally published version of this Article contained an error in Figure 5. In panel f, the right $y$-axis 'Strain energy (kbT)' was labelled 'Probability' and the left $y$-axis 'Probability' was labelled 'Strain energy (kbT)'. This error has now been corrected in both the PDF and HTML versions of the Article.

Published online: 07 February 2018

\begin{abstract}
(c) Open Access This article is licensed under a Creative Commons Attribution 4.0 International License, which permits use, sharing, adaptation, distribution and reproduction in any medium or format, as long as you give appropriate credit to the original author(s) and the source, provide a link to the Creative Commons license, and indicate if changes were made. The images or other third party material in this article are included in the article's Creative Commons license, unless indicated otherwise in a credit line to the material. If material is not included in the article's Creative Commons license and your intended use is not permitted by statutory regulation or exceeds the permitted use, you will need to obtain permission directly from the copyright holder. To view a copy of this license, visit http://creativecommons.org/licenses/by/4.0/.
\end{abstract}

(C) The Author(s) 2018

\footnotetext{
${ }^{1}$ Department of Mechanical and Aerospace Engineering, Seoul National University, 301-dong 116-ho, 1 Gwanak-ro, Gwanak-gu, Seoul 08826, Korea. ${ }^{2}$ Institute of Advanced Machines and Design, Seoul National University, 313-dong 320-ho, 1 Gwanak-ro, Gwanak-gu, Seoul 08826, Korea Correspondence and requests for materials should be addressed to D.-N.K. (email: dnkim@snu.ac.kr)
} 